\title{
The Genetic Variability of Prolactin and Signal Transducers and Activators of Transcription 5A (STAT5A) Genes in Bali Cattle
}

\author{
K. A. Paramitasari, C. Sumantri, \& Jakaria* \\ Department of Animal Production and Technology, Faculty of Animal Science, Bogor Agricultural University \\ Jalan Agatis, Kampus IPB Darmaga, Bogor 16680, Indonesia \\ (Received 22-04-2014; Reviewed 20-05-2014; Accepted 07-08-2014)
}

\begin{abstract}
The aim of this study was to identify the genetic variability of PRL and STAT5A genes in Bali cattle from Bali, West Nusa Tenggara (NTB), and South Sulawesi (SS) using PCR-RFLP method. A total of 262 Bali cattle were identified using $R s a I$ (PRL) and $A v a$ I (STAT5A) restriction enzymes. PRL gene exon 3, PRL gene exon 4, and STAT5A gene exon 7 amplifications resulted fragments with the lengths of $156 \mathrm{bp}, 294 \mathrm{bp}, 215 \mathrm{bp}$, respectively. Genotyping of PRL gene both at exon 3 and 4 produced three genotypes in Bali population and two genotypes in NTB and SS population. For the PRL gene, frequencies of A allele (exon 3) and G allele (exon 4) were dominant to the B allele (exon 3) and A allele (exon 4) across all populations. The results showed that STAT5A $\mid A v a I$ loci had monomorphic $\mathrm{C}$ allele. Heterozygosity values were found low at both exons 3 and 4 of PRL gene in all population. Sequence analysis results of PRL gene both for exons 3 and 4 showed that there was a mutation between adenine (A) and guanine (G) bases in the $R s a$ I recognized site, whereas in STAT5A gene we can confirm the existence of $A v a$ I restriction site (CICCGAG).
\end{abstract}

Key words: bali cattle, genetic polymorphism, PCR-RFLP, prolactin gene, STAT5A gene

\section{ABSTRAK}

Penelitian ini bertujuan untuk mengidentifikasi ada tidaknya polimorfisme gen PRL dan STAT5A pada sapi bali di tiga daerah pusat pembibitan sapi bali, yaitu: Bali, Nusa Tenggara Barat (NTB), dan Sulawesi Selatan (SS) dengan menggunakan metode PCR-RFLP. Sapi bali sebanyak 262 sampel dideteksi keragaman genetiknya menggunakan enzim restriksi $R s a I$ (PRL) dan $A v a I$ (STAT5A). Amplifikasi gen PRL ekson 3, gen PRL ekson 4, dan gen STAT5A ekson 7 menghasilkan fragmen dengan panjang masing-masing $156 \mathrm{bp}, 294 \mathrm{bp}$, dan $215 \mathrm{bp}$. Penentuan genotipe gen PRL ekson 3 dan ekson 4 menghasilkan tiga genotipe pada populasi di Bali dan dua genotipe pada populasi di NTB dan SS. Frekuensi alel A (ekson 3) dan alel G (ekson 4) lebih tinggi dibandingkan dengan alel B (ekson 3) dan alel A (ekson 4) untuk gen PRL. Hasil analisis menunjukkan bahwa lokus STAT5A|AvaI memiliki alel monomorfik C. Nilai heterozigositas ditemukan rendah pada gen PRL ekson 3 dan ekson 4 untuk seluruh populasi. Hasil sekuens fragmen gen PRL baik pada ekson 3 maupun ekson 4 menunjukkan adanya mutasi antara basa adenin (A) dengan guanin (G), sedangkan hasil analisis sekuens pada gen STAT5A dapat mengonfirmasi adanya situs restriksi enzim AvaI (CICCGAG).

Kata kunci: gen prolaktin, gen STAT5A, keragaman genetik, PCR-RFLP, sapi bali

\section{INTRODUCTION}

Bali cattle (Bos javanicus), a domesticated descendant of the wild Banteng (Bibos banteng) (Payne \& Rollinson, 1973 ) is one of Indonesian indigenous animal genetic resources. Bali cattle has advantages, one of which is its remarkable reproductive ability, especially under harsh environments and low-quality fodder (Talib,

*Corresponding author:

E-mail: jakaria_karman@yahoo.co.id
2002). Moreover, bali cattle known as the most preferred breed of cattle in the small holding system, because of their conditions, fertilities, and low calf mortalities (Purwantara et al., 2012).

Bali cattle represents approximately $31 \%$ of the total local cattle population in Indonesia (DGLAH, 2011). Population of Bali cattle, beside in Bali Island itself, have been widely distributed throughout the eastern islands of Indonesia. There were three major populations of bali cattle: South Sulawesi, East and West Nusa Tenggara, and Bali Island. Strategies to support implementation of conservation and breeding programmes can be made 
through the role of breeding centre in order to produce superior bali cattle breeding stock. This study focused in the three bali cattle breeding centres in Indonesia: West Nusa Tenggara (BPT-HMT Serading), South Sulawesi (Barru District), and Bali Island (Breeding Centre of bali cattle, Singosari Artificial Insemination Centre, and Baturiti District Artificial Insemination Centre).

Improvement of bali cattle genetic quality can be done by selection to obtain desirable genetic characteristics of Bali cattle, i.e. its high reproductive ability. Previous study reported that Bali cattle had high fertility rate, about $69 \%-83 \%$ (Talib, 2002), services per conception was $1.65 \pm 0.87$ (Siswanto et al., 2013), ages at first calving were $43.86 \pm 0.70$ mo (Gunawan et al., 2011) and $1104.51 \pm 23.82 \mathrm{~d}$ (Siswanto et al., 2013), and calving rates were $350.46 \pm 27.98 \mathrm{~d}$ (Siswanto et al., 2013) and 360.93 \pm 4.47 d (Gunawan et al., 2011).

Khatib et al. (2009) stated that there were several candidate genes that affected reproductive traits, some of which were prolactin gene and STAT5A gene. Prolactin (PRL) and signal transducers and activators of transcription 5A (STAT5A) are members of POU1F1 signaling pathway related to reproductive traits. Single gene analysis revealed significant associations of STAT5A gene with embryonic survival and fertilization rate. Moreover, the 2-ways interactions of POU1F1 and PRL genes analysis were found to be associated with significant effects on early embryonic survival

Prolactin is a polypeptide hormone, mainly synthesized and secreted by the lactotroph cells of the pituitary gland, but also produced by extrapituitary sites such as mammary gland, placenta, uterus, and T lymphocytes (Bachelot \& Binart, 2007). The bovine PRL gene was a candidate gene which is associated with reproduction and milk performance traits (Brym et al., 2005) because its role in female fertility, mammogenesis, lactogenesis, and galactopoiesis. The bPRL gene resides at chromosome 23 (Barendse et al., 1997), consists of five exons and separated by four introns. Single nucleotide polymorphism (SNP) of Adenine (A) - G (Guanine) was reported to give rise to a polymorphic PRLIRsaI site (Brym et al. 2005). Many studies in cattle breeds from various countries have demonstrated the association of PRL polymorphism with milk yield, fat percentage, and milk protein content (Brym et al., 2005; Dong et al., 2013; Mehmannavaz et al., 2009; Alipanah et al., 2007; Dybus et al., 2005; Lazebnaya et al., 2013). PRL I RsaI loci has been widely used as a marker for genetic characterization of cattle population.

Signal transducers and activators of transcription (STAT) known as mammary gland factor (MGF), was discovered as intracellular mediator of prolactin signaling and can activate transcription of milk protein genes in response to prolactin (Wakao et al., 1994). The bovine STAT5A gene localized in chromosome 19, consists of 19 exons coding for 794 amino acid chains (Seyfert et al., 2000). Flisikowski et al. (2003) reported that SNP within exon 7 of the bovine STAT5A gene as a substitution between cytosine and thymine at position of 6853 (C6853T). This mutation creates AvaI restriction site which can be detected by using PCR-RFLP method. Genetic polymorphisms of STAT5A gene at exon 7 were associated with meat production traits (Flisikowski et al., 2003), growth performance traits (Dario et al., 2009b), and milk production traits (Sadeghi et al., 2009).

Genetic characterization of reproductive traits marker was suggested to complete the base information in order to improve implementation of breeding and conservation of bali cattle. Identifications of genetic diversity in bali cattle were reported in previous study: GH $\mid$ AluI loci by Jakaria \& Noor (2011), GHR |AluI loci by Zulkharnaim et al. (2010), SNP in exon 4 of IGF-1 by Maskur et al. (2012). Until now, the characterization of PRL and STAT5A genes in Bali cattle has never been conducted, therefore the information of these candidate genes was not available. The objective of this research was to identify the genetic variabilty of PRL and STAT5A genes polymorphisms in bali cattle at three breeding centre regions (Bali, West Nusa Tenggara, and South Sulawesi) by using the PCR-RFLP method followed by direct sequencing.

\section{MATERIALS AND METHODS}

\section{Sample Sources}

The total numbers of bali cattle used in this study were 262 samples derived from three populations. Samples from Bali Island were taken from Breeding Centre of bali cattle (100 heads), Baturiti District Artificial Insemination Centre (22 heads), and Singosari Artificial Insemination Centre (28 heads). Samples from West Nusa Tenggara (NTB) were taken from BPT-HMT Serading (48 heads). Samples from South Sulawesi were taken from Barru District (64 heads). Samples were analyzed in the form of blood samples, semen samples, and DNA collections from Livestock Molecular Genetics Laboratory, Faculty of Animal Science, Bogor Agricultural University.

\section{DNA Extraction}

Genomic DNA was extracted from blood samples and semen samples by using phenol-chloroform method followed by ethanol precipitation (Sambrook et al. 1989) and the DNA was dissolved in elution buffer. The quality of the total genome extraction was performed by $1 \%$ agarose gel electrophoresis.

\section{DNA Amplification}

Three pairs of PCR primer were designed to amplify parts of exon 3 and exon 4 of PRL gene, and exon 7 of STAT5A gene, as described by Mitra et al. (1995), Brym et al. (2005), and Flisikowski et al. (2003), respectively (Table 1). The PCR was carried out in a reaction volume of $15 \mu \mathrm{L}$ containing $1 \mu \mathrm{L}$ genomic DNA template, 0.2 $\mu \mathrm{L}$ each primer, $0.3 \mu \mathrm{L}$ dNTPs (Thermo Scientific), 1 $\mu \mathrm{L} \mathrm{MgCl}_{2}, 0.05 \mu \mathrm{L}$ Taq polymerase (Thermo Scientific), $1.5 \mu \mathrm{L}$ 10xbuffer (Thermo Scientific), and $10.75 \mu \mathrm{L}$ distillated water. Amplification was carried out with a thermal cycler machine GeneAmp ${ }^{\circledR}$ PCR System 9700 (Applied Biosystem). The condition of thermal cycling consisted of predenaturation at $95^{\circ} \mathrm{C}$ for $5 \mathrm{~min}$, followed 
Table 1. Forward and reverse primers sequences for the amplification

\begin{tabular}{llcc}
\hline Gene & Sequence & Product size & References \\
\hline STAT5A exon 7 & F: 5'-CTG CAG TGG CGT TCT GAG AG-3' & 215 bp & Flisikowski et al. (2003) \\
& R: 5'-TGG TAC CAG GAC TGT AGC ACA T-3' & & Mitra et al. (1995) \\
PRL exon 3 & F: 5'-CGA GTC CTT ATG AGC TTG ATT CTT-3' & 156 bp & \\
PRL exon 4 & R: 5'-GCC TTC CAG AAG TCG TTT GTT TTC-3' & & Brym et al. (2005) \\
& F: 5'-CCA AAT CCA CTG AAT TAT GCT T-3' & 294 bp & \\
\hline
\end{tabular}

by 35 cycles of denaturation at $95^{\circ} \mathrm{C}$ for $10 \mathrm{~s}$, annealing at $60{ }^{\circ} \mathrm{C}$ for $20 \mathrm{~s}$, and extension at $72{ }^{\circ} \mathrm{C}$ for $30 \mathrm{~s}$. The final extension step was at $72{ }^{\circ} \mathrm{C}$ for $5 \mathrm{~min}$. The DNA amplification products were checked on $1.5 \%$ agarose gels in $0.5 \times$ TBE buffer containing with a $100 \mathrm{bp}$ ladder as a molecular weight marker.

\section{Genotyping by PCR-RFLP}

For the PCR-RFLP analysis, $5 \mu \mathrm{l}$ each PCR product was digested with $0.3 \mu \mathrm{L}$ RsaI enzyme for PRL gene and AvaI enzyme for STAT5A gene, $0.7 \mu \mathrm{L}$ Tango buffer, and $1 \mu \mathrm{l}$ distillated water at $37^{\circ} \mathrm{C}$ for $16 \mathrm{~h}$. A $100 \mathrm{bp}$ molecular weight marker (for PRL gene at exon 4 and STAT5A gene) and a $20 \mathrm{bp}$ molecular weight marker (for PRL gene at exon 3) were used to determine the length of digestion product. The digestion products were separated on $2 \%$ agarose gels (for PRL gene at exon 4 and STAT5A gene) and $3.5 \%$ agarose gels (for PRL gene at exon 3 ) in $0.5 \times$ TBE buffer by electrophoresing at 100 volt for 45 min and visualized on UV transiluminator.

\section{DNA Sequencing and Analysis}

PCR products representing different genotype of each gene were sequenced with DNA sequencer machine provided by DNA sequencing service in $1^{\text {st }}$ Base. Sequence results were analyzed by BioEdit (Hall, 1999) and sequence alignment was performed by using MEGA software version 5.0 (Tamura et al., 2011) in order to find nucleotide mutation. The BLAST (Basic Local Alignment Search Tool) program was used to search the NCBI GenBank databases for reference and homologous sequences.

\section{Data Analysis}

Genotype and allele frequencies. The genotype and allele frequencies as were described by Nei \& Kumar (2000) were analyzed by using genotyping data from each gene and calculated based on the populations of Bali cattle (Bali, NTB, and South Sulawesi). Genotype frequency was calculated by the following formula:

$$
\mathrm{X}_{\mathrm{ii}}=\mathrm{n}_{\mathrm{ii}} / \mathrm{N}
$$
formula:

Allele frequency was calculated by the following

$$
\mathrm{X}_{\mathrm{i}}=\left(2 \mathrm{n}_{\mathrm{ii}}+\sum \mathrm{n}_{\mathrm{ij}}\right) / 2 \mathrm{~N}
$$
Description:
$\mathrm{X}_{\mathrm{ii}}=\mathrm{ii}^{\text {th }}$ genotype frequency
$X_{i}=i^{\text {th }}$ allele frequency
$n_{\mathrm{ii}}=$ Number of sample of ij genotype
$n_{\mathrm{j}}$ = Number of sample of ij genotype
$\mathrm{N}=$ Total samples

Heterozygosity. Observed heterozygosity (Weir, 1996) and expected heterozygosity (Nei \& Kumar, 2000) were tested by the following formula:

$$
\begin{aligned}
& \mathrm{H}_{\mathrm{o}}=\sum_{\mathrm{i} \neq \mathrm{j}} \frac{\mathrm{n}_{\mathrm{ij}}}{\mathrm{N}} \\
& \mathrm{H}_{\mathrm{e}}=1-\sum_{\mathrm{i}=1}^{\mathrm{q}} \mathrm{x}_{\mathrm{i}}^{2} \\
& \text { Description: } \\
& \mathrm{H}_{\mathrm{o}}=\text { Observed heterozygosity } \\
& \mathrm{n}_{\mathrm{ij}}=\text { Number of heterozygous animal } \\
& \mathrm{N}=\text { Number of observed animal } \\
& \mathrm{H}_{\mathrm{e}}=\text { Expected heterozygosity } \\
& x_{\mathrm{i}}=\text { Frequency of allele } \\
& \mathrm{q}=\text { Total alleles }
\end{aligned}
$$

Hardy-Weinberg equilibrium. Test of Hardy-Weinberg equilibrium (HWE) was conducted with chi-square test (Kaps \& Lamberson, 2004) and was computed by using PopGene32 software version 1.32 (Yeh et al., 1999):

$$
\chi^{2}=\sum \frac{(\text { obs-exp })^{2}}{\exp }
$$

Description:

$\chi^{2}=$ Hardy Weinberg equilibrium test obs $=$ Observed number of $\mathrm{it}^{\text {th }}$ genotype $\exp =$ Expected number of $\mathrm{it}^{\text {th }}$ genotype

The number of degrees of freedom (df) is equal to the number of possible genotypes minus the number of alleles (Allendorf et al., 2013) or as decribed below:

$\mathrm{df}=\left(\right.$ number of $\mathrm{ii}^{\text {th }}$ genotype $)-\left(\right.$ number of $\mathrm{j}^{\text {th }}$ allele $)$

Genetic differentiation $\left(\mathrm{F}_{\mathrm{ST}}\right) . \mathrm{F}_{\mathrm{ST}}$ was based on Nei's Fstatistics (1977) and was computed by using PopGene32 software version 1.32 (Yeh et al., 1999):

$$
\text { Fst }=(\mathrm{Ht}-\mathrm{Hs}) / \mathrm{Ht}
$$

Description:

$\mathrm{Ht}=$ expected HW heterozygosity if the entire base population were panmitic 
Ho $=$ observed proportion of heterozygosity averaged over all subpopulations

$\mathrm{Hs}=$ expected heterozygosity averaged over all subpopulations.

\section{RESULTS AND DISCUSSION}

\section{Genetic Polymorphism of the PRL Gene}

PRL gene and STAT5A gene fragments were succesfully amplified by using polymerase chain reaction technique for all samples. The $156 \mathrm{bp}$ fragment of third exon of PRL gene, $294 \mathrm{bp}$ fragment of fourth exon of PRL gene, and $215 \mathrm{bp}$ fragment of seventh exon of STAT5A gene in bali cattle samples were shown in Figure 1.

PRLIRsaI restriction analysis of the exon 3 region revealed three genotypic patterns in bali cattle and showed two alleles (A and B alleles) in all bali cattle population. The restriction patterns were single fragment or uncut of $156 \mathrm{bp}$ (referred to AA genotype), two fragments of $82 \mathrm{bp}$ and $74 \mathrm{bp}$ (BB genotype), and three fragments of 156,82 , and 74 bp were the heterozygous AB genotype (Figure 2).

The genotype and allele frequencies of the third exon of PRL gene for bali cattle in all population were presented in Table 2. The homozygous AA genotype was present in the highest frequency across all the population. The frequency of AA genotype of Bali cattles in Bali (0.9133) was higher than those in NTB (0.7083) and South Sulawesi (0.8906). Frequency of the AB genotype in NTB population (0.2917) was higher than those in South Sulawesi (0.1094) and Bali (0.0801). The results showed that those bali cattle with the BB genotype were very low in Bali population (0.0066) and none of these animals had the BB genotype in NTB and South Sulawesi populations.

The distribution of the PRLIRsaI alleles of the third exon is characterized by a higher frequency of the A allele compared to the B allele in most bali cattle population studied (Table 2). The frequencies of the A allele in Bali and South Sulawesi populations almost similar (0.9533 vs 0.9543) while the A allele for bali cattle

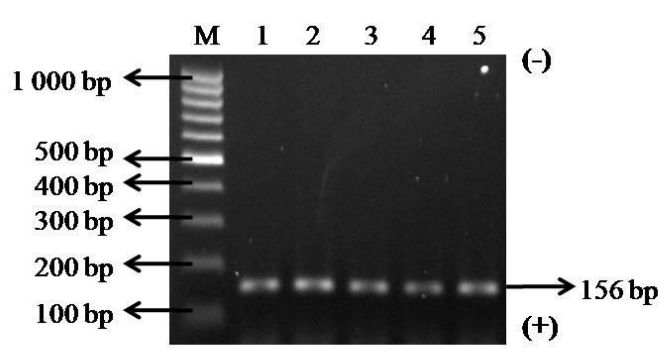

A. PRL exon 3

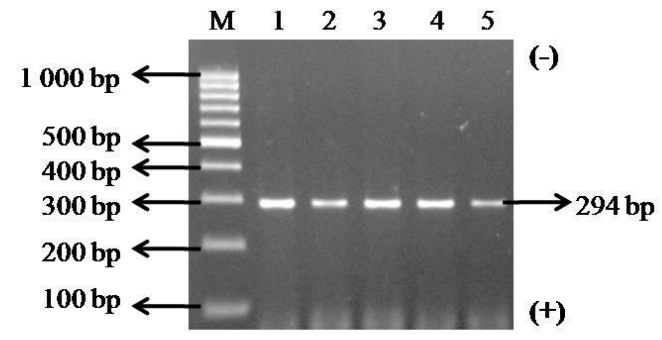

B. PRL exon 4

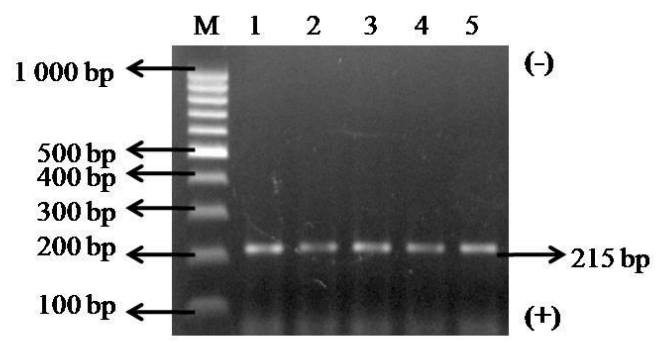

C. STAT5A exon 7

Figure 1. Visualization of PCR product amplified from bali cattle samples. (A) 1-5= PCR product of prolactin gene at exon 3 (156 bp); $\mathrm{M}=100 \mathrm{bp}$ ladder size standard. (B) 1-5= PCR product of prolactin gene at exon 4 (294 bp); M= $100 \mathrm{bp}$ ladder. (C) 1-5= PCR product of STAT5A gene at exon 7 (215 bp); M= 100 bp ladder.

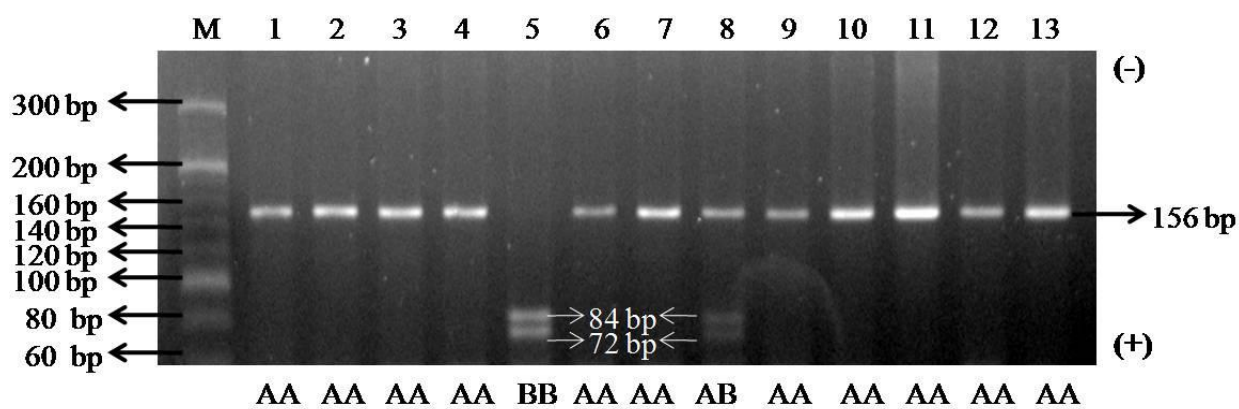

Figure 2. Restriction pattern of PRL gene at exon 3 fragment using PCR-RFLP method with RsaI enzyme on $3.5 \%$ agarose gel. M= 20 bp ladder size standard; 1-13= Number of samples; $\mathrm{AA}, \mathrm{AB}, \mathrm{BB}=$ Genotype. 
population in NTB was lower (0.8542) with regarding to the higher $\mathrm{AB}$ genotype at NTB. In general, the A allele frequency of the PRL gene at exon 3 of bali cattle identified in this study was higher than those reported in some cattle breeds such as Bos indicus (0.52, Sodhi et al., 2011), Russian Red Pied (0.794, Alipanah et al., 2007), Black-and-White (0.8533, Dybus et al., 2005), Nadji (0.571, Roshanfekr et al., 2013), Turkish Grey (0.762, Akyuz et al., 2012), Simmental (0.810, Akyuz et al. 2013), Holstein-Friesian (0.582, Wojdak-Maksymiec et al., 2008), and Aboriginal Russian (0.732, Lazebnaya et al., 2013). This study confirmed the predominance of the A allele across three bali cattle populations in Indonesia.

Lazebnaya et al. (2013) reported the association of $\mathrm{AA}$ and $\mathrm{AB}$ genotypes at PRL at exon $3 \mid R s a \mathrm{I}$ locus with higher fat content of milk than BB genotype. Contrastly, Alipanah et al. (2007) reported that animals with BB genotype had higher milk production, milk fat yield, and milk protein yield in Russian Red Pied cattle.

RFLP (restriction fragment length polymorphism) analysis using $R s a \mathrm{I}$ restriction enzyme was used to genotyping PRL gene of the fourth exon. Digestion of the 294 bp PCR product resulted in three restriction patterns. The first pattern, with two restriction fragments of 162 and $132 \mathrm{bp}$ was referred to as AA genotype. The second pattern was lacking restriction site and showed one uncut fragment of $294 \mathrm{bp}$ (GG genotype). The third pattern with all three fragments $(294,162,132 \mathrm{bp})$ for AG heterozygotes (Figure 3).

The results of the genotype and allele frequency in bali cattle based on population were shown in Table 3. The GG genotype frequencies was higher compared with AA and AG genotypes. Frequencies of animals with GG genotype in Bali (0.9133) were the highest compared than those in NTB (0.750) and South Sulawesi (0.8750). The AG genotype frequencies in Bali (0.0801) and South Sulawesi (0.150) were lesser compared to AG genotype in NTB (0.250). Frequencies of AA genotype were very low (0.0066) in Bali, on the other hand none of these bali cattle was identified having the AA genotype at NTB and South Sulawesi. This situation could be becoming an indication for a limited number of AA genotype in bali cattle breeding centres.

The frequencies of the $G$ allele in Bali and South Sulawesi populations almost similar (0.9533 vs 0.9375$)$ while the $G$ allele for bali cattle population in NTB was lower (0.8570). The low G allele (0.8750) at NTB might be due to limited number of the heterozygous AG genotype in this population. The $G$ allele frequency of the PRL gene at exon 4 of bali cattle identified in this study was higher than those in some cattle breeds such as Chinese Holstein (0.8754, Dong et al., 2013; 0.893, Lü et al., 2010), Iranian Holstein (0.931, Mehmannavaz et al., 2009), Colombia Holstein (0.833, Rincon et al., 2011), Sahiwal (0.810, Ishaq et al., 2013), Achai (0.560, Ishaq et al., 2013), and Black-and-White, (0.887, Brym et al., 2005).

Brym et al. (2005) in their study about association of bovine prolactin gene exon 4 polymorphism with milk performance traits in Black-and-White cattle revealed that cows with AG genotype showed the highest milk yield, while cows with GG genotype showed the highest fat content. Contrastly, Dong et al. (2009) reported that the $G$ allele was unfavourable for milk and protein yield.

\section{Genetic Polymorphism of the STAT5A Gene}

One genotypic pattern was produced as the result of AvaI enzyme digestion. The enzyme cuts the amplified $215 \mathrm{bp}$ product into 181 and $34 \mathrm{bp}$ fragments for allele C (Figure 4). Table 4 showed there was no genotype variation in bali cattle across all the population studied. Genotype frequencies of STAT5A gene at exon 7 were 1.00 for CC. Thus, the allele frequencies were 1.00 for $\mathrm{C}$ allele. The STAT5A $\mid$ AvaI loci was in fixation because all population had equal allele frequencies or known as monomorphic allele.

Table 2. Allelic and genotypic frequencies values of PRL gene exon 3 based on population

\begin{tabular}{|c|c|c|c|c|c|c|}
\hline \multirow{2}{*}{ Population } & \multirow{2}{*}{$\begin{array}{l}\text { Number of } \\
\text { samples }\end{array}$} & \multicolumn{3}{|c|}{ Genotype frequency } & \multicolumn{2}{|c|}{ Allele frequency } \\
\hline & & AA & $\mathrm{AB}$ & $\mathrm{BB}$ & $\mathrm{A}$ & B \\
\hline Bali & 150 & $\begin{array}{c}0.9133 \\
(137)\end{array}$ & $\begin{array}{c}0.0801 \\
(12)\end{array}$ & $\begin{array}{c}0.0066 \\
(1)\end{array}$ & 0.9533 & 0.0467 \\
\hline NTB & 48 & $\begin{array}{c}0.7083 \\
(34)\end{array}$ & $\begin{array}{c}0.2917 \\
(14)\end{array}$ & $\begin{array}{c}0.000 \\
(0)\end{array}$ & 0.8542 & 0.1458 \\
\hline South Sulawesi & 64 & $\begin{array}{c}0.8906 \\
(57)\end{array}$ & $\begin{array}{c}0.1094 \\
(7)\end{array}$ & $\begin{array}{c}0.000 \\
(0)\end{array}$ & 0.9453 & 0.0547 \\
\hline
\end{tabular}

Table 3. Allelic and genotypic frequencies values of PRL gene exon 4 based on population

\begin{tabular}{|c|c|c|c|c|c|c|}
\hline \multirow{2}{*}{ Population } & \multirow{2}{*}{$\begin{array}{l}\text { Number of } \\
\text { samples }\end{array}$} & \multicolumn{3}{|c|}{ Genotype frequency } & \multicolumn{2}{|c|}{ Allele frequency } \\
\hline & & $\mathrm{AA}$ & AG & GG & $\mathrm{A}$ & G \\
\hline Bali & 150 & $\begin{array}{c}0.0066 \\
(1)\end{array}$ & $\begin{array}{c}0.0801 \\
(12)\end{array}$ & $\begin{array}{c}0.9133 \\
(137)\end{array}$ & 0.0467 & 0.9533 \\
\hline NTB & 48 & $\begin{array}{c}0.000 \\
(0)\end{array}$ & $\begin{array}{c}0.2500 \\
(12)\end{array}$ & $\begin{array}{c}0.7500 \\
(36)\end{array}$ & 0.1250 & 0.8570 \\
\hline South Sulawesi & 64 & $\begin{array}{c}0.000 \\
(0)\end{array}$ & $\begin{array}{c}0.1250 \\
(8)\end{array}$ & $\begin{array}{c}0.8750 \\
(56)\end{array}$ & 0.0625 & 0.9375 \\
\hline
\end{tabular}




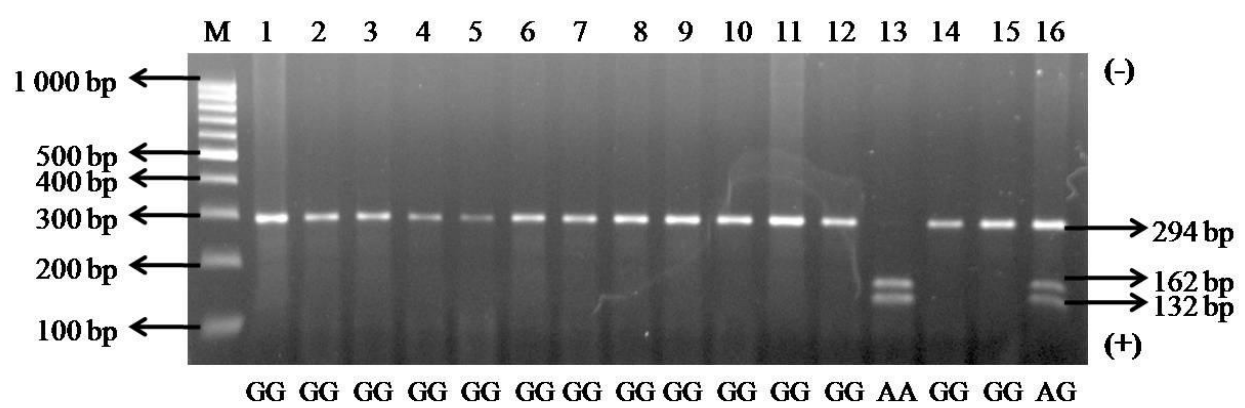

Figure 3. Restriction pattern of PRL gene at exon 4 fragment using PCR-RFLP method with RsaI enzyme on $2 \%$ agarose gel. M=100 bp ladder size standard; 1-16= Number of samples; AA, AG, GG= Genotype.

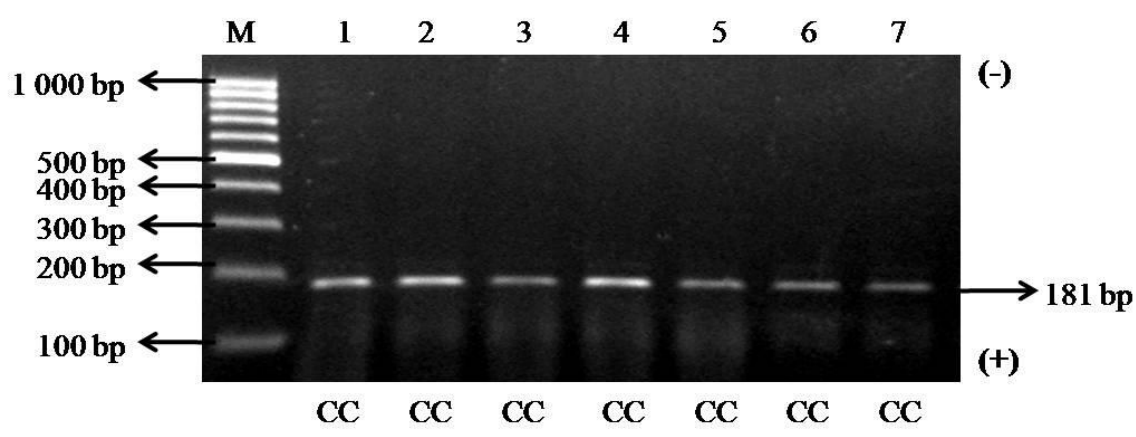

Figure 4. Restriction pattern of STAT5A gene at exon 7 fragment using PCR-RFLP method with AvaI enzyme on $2 \%$ agarose gel. M= 100 bp ladder size standard; $1-7=$ Number of samples; CC= Genotype.

Table 4. Allelic and genotypic frequencies values of STAT5A gene exon 7 based on population

\begin{tabular}{|c|c|c|c|c|c|c|}
\hline \multirow{2}{*}{ Population } & \multirow{2}{*}{$\begin{array}{l}\text { Number of } \\
\text { samples }\end{array}$} & \multicolumn{3}{|c|}{ Genotype frequency } & \multicolumn{2}{|c|}{ Allele frequency } \\
\hline & & $\mathrm{CC}$ & $\mathrm{CT}$ & TT & $\mathrm{C}$ & $\mathrm{T}$ \\
\hline Bali & 150 & $\begin{array}{l}1.000 \\
(150)\end{array}$ & $\begin{array}{c}0.000 \\
(0)\end{array}$ & $\begin{array}{c}0.000 \\
(0)\end{array}$ & 1.000 & 0.000 \\
\hline NTB & 48 & $\begin{array}{c}1.000 \\
(48)\end{array}$ & $\begin{array}{c}0.000 \\
(0)\end{array}$ & $\begin{array}{c}0.000 \\
(0)\end{array}$ & 1.000 & 0.000 \\
\hline South Sulawesi & 64 & $\begin{array}{c}1.000 \\
(64)\end{array}$ & $\begin{array}{c}0.000 \\
(0)\end{array}$ & $\begin{array}{c}0.000 \\
(0)\end{array}$ & 1.000 & 0.000 \\
\hline
\end{tabular}

Genetic polymorphism of STAT5AIAvaI was reported in Italian cattle (Dario et al., 2009a), Podolica (Dario et al., 2009b), Jersey (Dario \& Selvaggi, 2011), Polish Red-and-White (Kmiec et al., 2010), beef cattle breeds (Flisikowski et al., 2003), Italian Brown (Selvaggi et al., 2009), and Iranian Holstein (Sadeghi et al., 2009). Contrary to that, this study found STAT5A $\mid$ AvaI locus monomorphic and fixed with $C$ allele in all populations. This monomorphisms confirmed the predominance of the $\mathrm{C}$ allele in bali cattle and resulted in restrictiveness of genetic diversity usage of the STAT5A gene exon 7 . Monomorphism in bali cattle were reported previously by Zulkharnaim et al. (2010) in GHR|AluI loci, Ishak et al. (2011) in FSH beta-subunit|PstI loci, Mu'in \& Supriyantono (2012) in $\kappa$-casein I HindIII loci, and Jakaria \& Noor (2011) in GHI AluI loci.

According to Dario et al. (2009b), the STAT5A gene is a candidate marker for quantitative traits in livestock animals and the study reveals that CC and CT bulls show a higher live weight and a faster growth. Khatib et al. (2008) states that STAT5A gene is a candidate gene because it is a member of interferon- $\tau$ (IFN- $\tau$ ) and placental lactogen (PL) signal transduction pathways, which plays important roles in reproduction and milk production traits.

\section{Hardy-Weinberg Equilibrium}

The result of chi-square $\left(\chi^{2}\right)$ test showed that the distribution of genotypes derived from third and fourth exon of PRL gene in Bali Island population was in Hardy-Weinberg equilibrium. Hardy-Weinberg equilibriums for both at exon 3 and exon 4 of PRL gene in NTB and South Sulawesi population were also in Hardy-Weinberg equilibrium (Table 5). Hardy-Weinberg equilibrium for STAT5A gene in all population could not be analyzed because the allele frequency $(\mathrm{C})$ was 1.00. A certain population was in Hardy-Weinberg equilibrium if the genotype frequencies and allele frequencies were constant from one generation to the next generation 
Table 5. Heterozygosity and Hardy-Weinberg equilibrium (HWE) values of bali cattle based on population

\begin{tabular}{|c|c|c|c|c|c|}
\hline \multirow{2}{*}{ Gene } & \multirow{2}{*}{ Population } & \multirow{2}{*}{$\begin{array}{l}\text { Number of } \\
\text { samples }\end{array}$} & \multicolumn{2}{|c|}{ Heterozygosity } & \multirow{2}{*}{ HWE } \\
\hline & & & $\mathrm{H}_{\text {observed }}$ & $\mathrm{H}_{\text {expected }}$ & \\
\hline \multirow[t]{3}{*}{ PRL exon 3} & Bali & 150 & 0.0800 & 0.0893 & $1.738164^{\mathrm{ns}}$ \\
\hline & NTB & 48 & 0.2917 & 0.2518 & $1.287865^{\mathrm{ns}}$ \\
\hline & South Sulawesi & 64 & 0.1094 & 0.1042 & $0.182231^{\text {ns }}$ \\
\hline \multirow[t]{3}{*}{ PRL exon 4} & Bali & 150 & 0.0800 & 0.0893 & $1.738164^{\mathrm{ns}}$ \\
\hline & NTB & 48 & 0.2500 & 0.2211 & $0.889845^{\mathrm{ns}}$ \\
\hline & South Sulawesi & 64 & 0.1250 & 0.1181 & $0.247059^{\mathrm{ns}}$ \\
\hline \multirow[t]{3}{*}{ STAT5A exon 7} & Bali & 150 & 0.0000 & 0.0000 & undefined \\
\hline & NTB & 48 & 0.0000 & 0.0000 & undefined \\
\hline & South Sulawesi & 64 & 0.0000 & 0.0000 & undefined \\
\hline
\end{tabular}

Note: $n s=$ not significant at level $X^{2} \mathrm{df}=1, \alpha 5 \%=3.84$.

that resulted from gametes fussion randomly in large population size (Allendorf et al., 2013). Compared with heterozigosity values for PRL gene at exon 3 and exon 4, the genotype frequencies were also in equilbrium for all populations. The genotype frequencies equilibrium of PRL gene might suggested that selection in PRL I RsaI locus was not occured in all bali cattle population studied.

\section{Heterozygosity}

According to Marson et al. (2005), the genetic diversity of population can be measured by using heterozygosity value with a purpose to help selection program. Heterozygosity values (Table 5) showed that PRLIRsaI at exon 3 and exon 4 regions in West Nusa Tenggara (NTB) population had the highest heterozygosity values ( 0.2917 and 0.2500 , respectively) followed by lower heterozygosity values in South Sulawesi population (0.1094 and 0.1250 , respectively) while heterozygosity value in Bali population for the same locus had the lowest heterozygosity value (0.0800). Analysis results of the observed heterozygosity $\left(\mathrm{H}_{\mathrm{o}}\right)$ and expected heterozygosity $\left(\mathrm{H}_{\mathrm{e}}\right)$, both for exon 3 and exon 4 of PRL gene indicated that the genotype frequencies from all populations studied were in equilibrium as compared with Hardy-Weinberg equilibrium.

However, from overall heterozygosity values showed that the lowest heterozygosity value was found in STAT5A I AvaI locus (0.000) in all populations due to monomorphic $\mathrm{C}$ allele. The results of heterozygosity values in this study were low as described by Javanmard et al. (2005) that if the heterozygosity value was below 0.5 then the variabilty of certain gene in the population was low. Low heterozigosity values for all loci in this study indicated the occurance of inbreeding within bali cattle population studied. Different number of samples might cause the difference in heterozygosity value.

The implementation of breeding program for Bali cattle over the past years was not well directed and sustained. The largest and the best bali cattles usually slaughtered so that negative selection occured in bali cattle population. The decreasing of bali cattle genetic diversity causes alteration in the genotype proportion and only animals that have certain genotype that were available to be inherited to the next descendants. Government implemented a national program that aims to improve the genetic quality and purity of bali cattle in Bali Island since 1976 through P3 Bali (Bali Cattle Development and Breeding Project) based on Decree of The Minister of Agriculture no. 776/Kpts/Um/12/1976. This project works through selection within bali cattle breed to obtain good quality breed of bali cattle. Centralization and genetic purification of bali cattle in certain areas for long period of time led to inbreeding. Noor (2008) states that inbreeding is a form of genetic isolation due to the isolated population will lead to limitations in the choice of mating. Thus the homozygous alleles will passed on to the offspring.

\section{Genetic Differentiation $\left(\mathrm{F}_{\mathrm{ST}}\right)$}

$\mathrm{F}_{\mathrm{ST}}$ is the correlation between two gametes drawn at random from each subpopulation and measures the degree of genetic differentiation of subpopulations (Nei, 1977). The average genetic differentiation (Fst) among populations was $2.14 \%$ (Table 6 ), only PRL loci both at exon 3 and exon 4 contribute to this differentiation. With an exception, the STAT5A $\mid$ AvaI loci is in fixation because all populations have equal allele frequencies $(\mathrm{C}$ allele= 1.00) or known as monomorphic allele.

\section{Sequence Analysis of PRL Gene}

Sequence analysis using forward and reverse primer revealed that PCR product of PRL gene exon 3 in this study was similar with the 156 bp in length based on previously reported by Sodhi et al. (2011). The results of sequence alignment compared with Bos taurus GenBank (accession number AY339391 and AF426315) showed that a mutation occured in exon 3 of PRL gene (Figure 5) that caused a lack of $R s a \mathrm{I}$ restriction site (GT $\mid A C)$. Lewin

Table 6. $\mathrm{F}_{\mathrm{ST}}$ values of bali cattle based on loci

\begin{tabular}{lcc}
\hline Gene & Number of samples & $\mathrm{F}_{\text {ST }}$ \\
\hline PRL exon 3 & 262 & 0.0268 \\
PRL exon 4 & 262 & 0.0159 \\
STAT5A exon 7 & 262 & 0.0000 \\
Means & 262 & 0.0214 \\
\hline
\end{tabular}




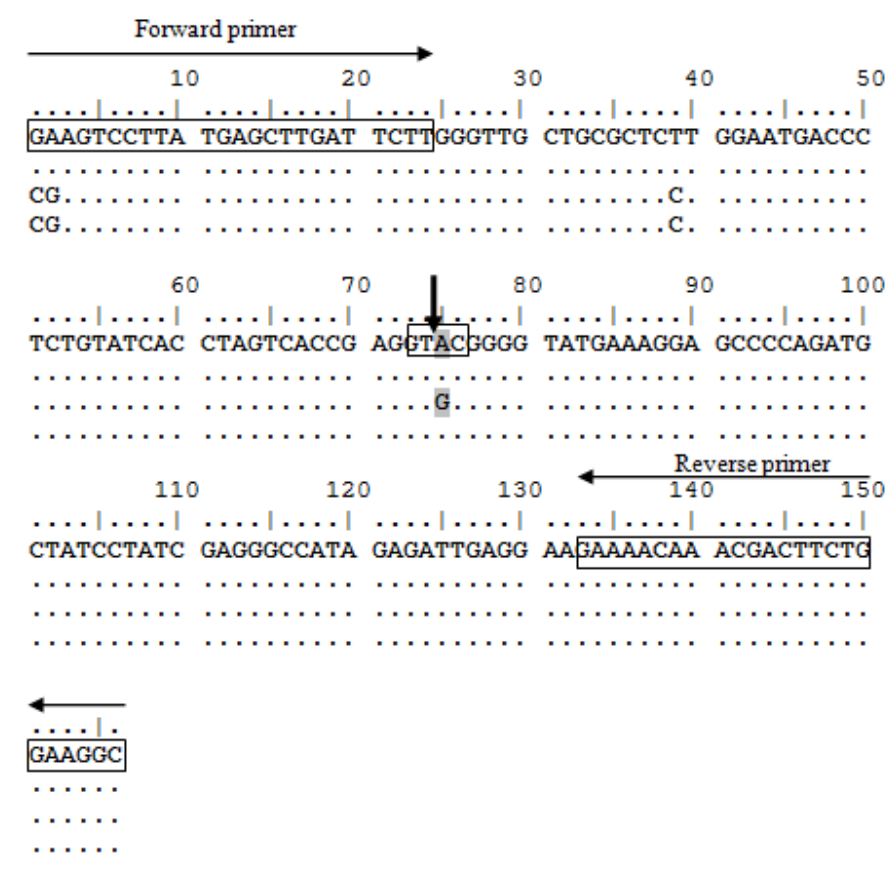
Bos taurus_GenBank AY339391.1
Bos taurus_GenBank AF426315.1 bali cattle 1 AA genotype bali cattle 2- BB genotype
Bos taurus_GenBank AY339391.1 Bos taurus_GenBank AF426315.1 bali cattle 1 AA genotype bali cattle 2- BB genotype

Bos taurus_GenBank AY339391.1 Bos taurus_GenBank AF426315.1 bali cattle 1 AA genotype bali cattle 2- $\mathrm{BB}$ genotype

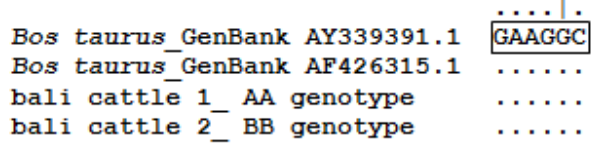

A allele: 5'-CACCGAGGTACGGGGTATGA-3'

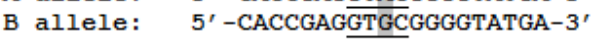

Figure 5. Nucleotide sequences alignment results of PRL gene at exon 3. GenBank of PRL sequences (accession number AY339391 and AF426315) were used for reference to find nucleotide mutation. $\downarrow=$ Restriction sites of RsaI restriction enzyme (GT |AC); $\ldots . .=$ Homologous sequences.

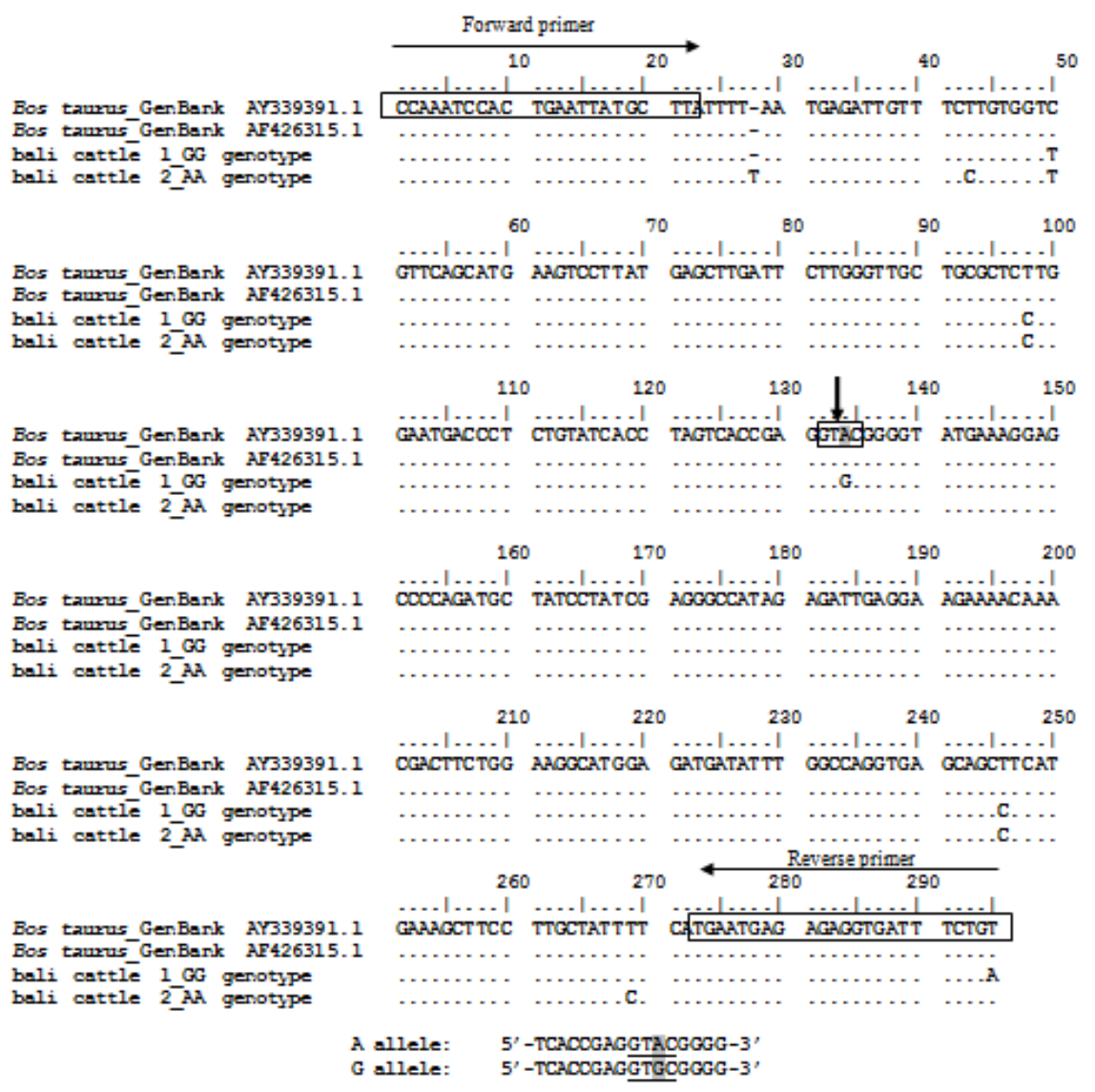

Figure 6. Nucleotide sequences alignment results of PRL gene at exon 4. GenBank of PRL sequences (accession number AY339391 and AF426315) were used for reference to find nucleotide mutation. $\downarrow=$ Restriction sites of RsaI restriction enzyme (GT IAC); $\ldots . .=$ Homologous sequences. 


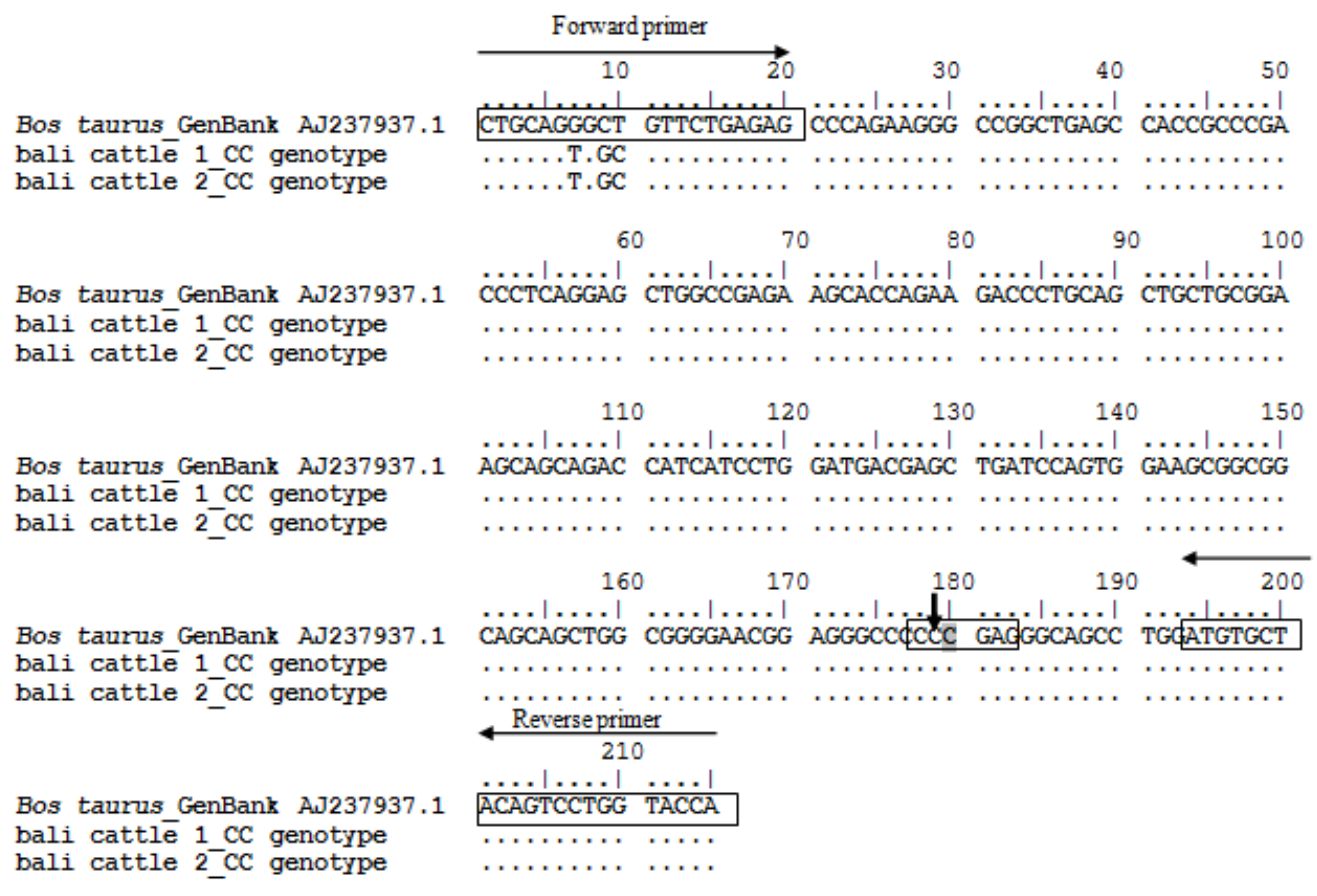

C allele: 5' - AGGGCCCCCCGAGGGCAG-3'

T allele: 5' - AGGGCCCCCTGAGGGCAG-3'

Figure 7. Nucleotide sequences alignment results of STAT5A gene at exon 7. GenBank of STAT5A sequences (accession number AJ237937) were used for reference to find nucleotide mutation. $\downarrow=$ Restriction sites of Aval restriction enzyme (CIYCGRG); $\ldots . .=$ Homologous sequences

et al. (1992) reported that there was a synonimous A-G transition mutation found in the codon of amino acid residue 103 in the third exon of bovine PRL and resulted in a $R s a \mathrm{I}$ polymorphic site. Transition mutation between adenine (A) base with guanine $(G)$ base in bali cattle individual with AA genotype causing alteration in $R s a \mathrm{I}$ restriction site sequences GTI $\underline{A C}$ became GTI GC so that the $R s a I$ enzyme couldn't recognize its restriction site.

Similar A-G transition mutation was detected in $R s a \mathrm{I}$ restriction site in the fourth exon of PRL gene (Figure 6). The GG genotype represented mutation of A into $G$ that produced uncut fragment in $294 \mathrm{bp}$. This result was similar to that previously described by Brym et al. (2005) that a transition A-G SNP (single nucleotide polymorphism) in position $8398 \mathrm{R}$ including part of exon 4 of PRL gene was found by using PCR-SSCP and direct squencing methods. Association between this SNP with milk performance traits in Black-and-White cows resulted that cows with GG genotype showed higher fat contents in the first lactation and AG genotype resulted in significantly higher milk yield. Mehmannavaz et al. (2009) reported that the A-G mutation in PRLIRsaI recognition site for both of bases is a silent mutation (Val/Val).

\section{Sequence Analysis of STAT5A Gene}

Based on sequence analysis of STAT5A gene by sequence comparison with Bos taurus STAT5A exon 7 fragment sequence deposited in the GenBank (accession number AJ237937.1), it was identified that there was no mutation occured in the AvaI restriction site (CIYCGRG). Figure 7 showed that the $A v a \mathrm{I}$ enzyme recognized its restriction sequence (CICCGAG) and produced two fragments which were being cut, namely CC genotype or $C$ allele. IUPAC single-letter codes were used to facilitate the definition of nucleotide sequences, which are $\mathrm{Y}$ symbol for pyrimindine $(\mathrm{C}$ or $\mathrm{T} / \mathrm{U})$ and $\mathrm{R}$ symbol for purine (A or $G$ ). This sequence analysis results confirmed that STAT5A $\mid$ AvaI locus in all bali cattle population studied was monomorphic. SNP in exon 7 of the bovine STAT5A gene was a substitution of $\mathrm{C}$ (cytosine) and $\mathrm{T}$ (thymine) at position 6853. This mutation resulted in silent mutation because CCC and CCT triplets both coded for the amino acid proline (Flisikowski et al., 2003).

\section{CONCLUSION}

PRLIRsaI loci both at third and fourth exons in all populations are polymorphic, whereas STAT5AIAvaI loci is monomorphic and fixed with $\mathrm{C}$ allele. Bali cattle across all the populations for PRL gene are in low level of heterozygosity. Sequence analysis results confirm a mutation of $A \rightarrow G$ base in PRL gene and the occurance of $\mathrm{C}$ allele in STAT5A gene.

\section{ACKNOWLEDGEMENT}

The work was supported by DIPA IPB and Directorate General of Higher Education (DGHE), Ministry of National Education Republic of Indonesia through Fundamental Research 2013 with contract no. 
18./IT3.41.2/L1/SPK/2013 and and Fundamental Research INSinas 2014 by Ministry of Research and Technology with contract no. 25/SEK/INSINAS/PPK/I/2014.

\section{REFERENCES}

Akyuz B., O. Kagaoglu, \& O. Ertugrul. 2012. Genetic polymorphism of kappa-casein, growth hormone, and prolactin genes in Turkish native cattle breeds. Intl. J. Dairy Sci. 65:38-44. http://dx.doi.org/10.1111/j.1471-0307.2011.00732.

Akyuz B., K. Arslan, D. Bayram, \& K. M. Iscan. 2013. Allelic frequency of kappa-casein, growth hormone, and prolactin gene in Holstein, Brown Swiss, and Simmental cattle breeds in Turkey. Kafkas Univ. Vet. Fak. Derg. 19:439-444.

Allendorf, F. W., G. Luikart, \& S. N. Aitken. 2013. Conservation and The Genetics of Populations. $2^{\text {nd }}$ ed. Wiley-Blackwell, UK.

Alipanah, M., L. Kalashnikova, \& G. Rodionov. 2007. Association of prolactin gene variants with milk production traits in Russian Red Pied cattle. Iranian J. Biotechnol. 5: 158-161.

Bachelot A., \& N. Binart. 2007. Reproductive role of prolactin. Reproduction. 133: 361-369. http://dx.doi.org/10.1530/REP06-0299

Barendse, W., D. Vaiman, S. J. Kemp, Y. Sugimoto, S. M. Armitage, J. L. Williams, H. S. Sun, A. Eggen, M. Agaba, M. Band, M. D. Bishop, J. Buitkamp, K. Byrne, F. Collins, L. Cooper, W. Coppieters, B. Denys, \& R. D. Drinkwater. 1997. A medium-density genetic linkage map of the bovine genome. Mamm. Genome. 8: 21-28. http://dx.doi. org/10.1007/s003359900340

Brym, P., S. Kaminski, \& E. Wojcik. 2005. Nucleotide sequence polymorphism within exon 4 of the bovine prolactin gene and its associations with milk performance traits. J. Appl. Genet. 45: 179-185.

Dario, C., M. Dario, F. Ciotola, V. Peretti, D. Carnicella, \& M. Selvaggi. 2009a. Analysis of STAT5A/AvaI gene polymorphism in four Italian cattle breeds. Biochem. Genet. 47: 671-679. http://dx.doi.org/10.1007/s10528-009-9263-1

Dario, C., M. Selvaggi, D. Carnicella, \& G. Bufano. 2009b. STAT5A/AvaI polymorphism in Podolica bulls and its effect on growth performance traits. Liv. Sci. 123: 83-87. http://dx.doi.org/10.1016/j.livsci.2008.10.011

Dario C. \& M. Selvaggi. 2011. Study on the STAT5A/AvaI polymorphism in Jersey cows and association with milk production traits. Mol. Biol. Rep. 38:5387-5392. http://dx.doi. org/10.1007/s11033-011-0691-8

DGLAH (Directorat General Livestock and Animal Health). 2011. Pendataan Sapi Potong, Sapi Perah, dan Kerbau 2011 (PSPK 2011). Badan Pusat Statistik, Jakarta.

Dong, C.H., X. M. Song, L. Zhang, J. F. Jiang, J. P. Zhou, \& Y. Q. Jiang. 2013. New insights into the prolactin-RsaI (PRLRsaI) locus in Chinese Holstein cows and its effect on milk performance traits. Genet. Mol. Res. 12: 5766-5773. http:// dx.doi.org/10.4238/2013.November.22.3

Dybus, A., W. Grzesiak, H. Kamieniecki, I. Szatkowska, Z. Sobek, P. Błaszczyk, E. Czerniawska-Pia tkowska, S. Zych, \& M. Muszyn'ska. 2005. Association of genetic variants of bovine prolactin with milk production traits of Black-and-White and Jersey cattle. Arch. Tierz. 48: 149156.

Flisikowski, K., J. Oprzdek, E. Dymnicki, \& L. Zwierzchowski. 2003. New polymorphism in bovine STAT5A gene and its association with meat production traits in beef cattle. Anim. Sci. Pap. Rep. 21: 147-157.

Gunawan, A., R. Sari, Y. Parwoto, \& M. J. Uddin. 2011. Non genetics factors effect on reproductive performance and preweaning mortality from artificially and naturally bred in bali cattle. JITAA. 36: 83-90.

Hall, T.A. 1999. BioEdit: a user-friendly biological sequence alignment editor and analysis program for Windows 95/98/NT. Nucl. Acids. Symp. Ser. 41: 95-98.

Ishak, A.B.L., C. Sumantri, R. R. Noor, \& I. Arifiantini. 2011 Identification of polymorphism of FSH beta-subunit gene as sperm quality marker in bali cattle using PCRRFLP. JITAA. 36:221-227. http://dx.doi.org/10.1111/j.14710307.2012.00875.x

Ishaq R., M. Suleman, M. N. Riaz, M. Yousaf, A. Shah, \& A. Ghafoor. 2013. Prolactin gene polymorphism in Nili-Ravi buffaloes in relation to Sahiwal and Achai cattle. Intl. J. Dairy Sci. 66:20-24.

Jakaria \& R. R. Noor. 2011. Analysis on Alu-1 growth hormone (GHAlu-1) gene in bali cattle. JITAA. 1: 1-6.

Javanmard, A., N. Asadazadeh., M. H. Banabazi, \& J. Tavakolian. 2005. The allele and genotype frequencies of bovine pituitary specific transcription factor and leptin genes in Iranian cattle and buffalo populations using PCR-RFLP. Iranian J. Biotechnol. 3: 104-108.

Kaps, M. \& W. R. Lamberson. 2004. Biostatistics for Animal Science. CABI Publishing, London. http://dx.doi.org/10.1079/ 9780851998206.0000

Khatib, H., R. L. Monson, V. Schutzkus, D. M. Kohl, G. J. M. Rossa, \& J. J. Rutledge. 2008. Mutations in the STAT5A gene are associated with embryonic survival and milk composition in cattle. J. Dairy Sci. 91: 784-793. http://dx.doi. org/10.3168/jds.2007-0669

Khatib, H., W. Huang, X. Wang, A. H. Tran, A. B. Bindrim, V. Schutzkus, R. L. Monson, \& B. S. Yandell. 2009. Single gene and gene interaction effects on fertilization and embryonic survival rates in cattle. J. Dairy Sci. 92: 2238-22447. http://dx.doi.org/10.3168/jds.2008-1767

Kmiec M., I. Kowalewska-Luczak, K. Wodjak-Maksymiec, H. Kulig, \& T. Grzelak. 2010. STAT5A/AvaI restriction polymorphism in cows of Polish Red-and-White variety of Holstein Friesian breed. Russ. J. Genet. 46:81-85. http://dx.doi. org/10.1134/S1022795410010126

Lazebnaya, I. V., O. E. Lazebny, S. R. Khatami, \& G. E. Sulimova. 2013. Use of the bovine prolactin gene (bPRL) for estimating genetic variation and milk production in $\mathrm{Ab}$ original Russian breeds of Bos taurus L. InTech. Chapter 3: 35-52.

Lewin, H. A., K. Schmitt, R. Hubert, M. J. Van Eijk, \& N. Arnheim. 1992. Close linkage between bovine prolactin and BoLA-DRB3 genes, genetic mapping in cattle by single sperm typing. Genomics. 13: 44-48.

Lü A., X. Hu, H. Chen, J. Jiang, C. Zhang, H. Xu, \& X. Gao. 2010. Single nucleotide polymorphisms in bovine PRL gene and their associations with milk production traits in Chinese Holsteins. Mol. Biol. Rep. 37:547-551. http://dx.doi. org/10.1007/s11033-009-9762-5

Marson, E. P., J. B. S. Ferraz, F. V. Meirelles, J. C. C. Balieiro, J. P. Eler, L. G. G. Figuerido, \& G. B. Mourao. 2005. Genetic characterization of European-Zebu composite bovine using RFLP markers. Genet. Mol. Res. 4: 496-505.

Maskur, C., Arman, C. Sumantri, E. Gunardi, \& Muladno. 2012. A novel single nucleotide polymorphism in exon 4 of Insulin-Like Growth Factor-1 associated with production traits in bali cattle. Med. Pet. 35: 96-101. http://dx.doi. org/10.5398/medpet.2012.35.2.96

Mehmannavaz, Y., C. Amirinia, M. Bonyadi, \& R. V. Torshizi. 2009. Effects of bovine prolactin gene polymorphism within exon 4 on milk related traits and genetic trends in Iranian Holstein bulls. Afr. J. Biotechnol. 8: 4797-4801.

Mitra, A., P. Schlee, C. R. Balakrishnan, \& F. Pirchner. 1995. Polymorphism at growth hormone and prolactin loci in Indian cattle and buffalo. J. Anim. Breed. Genet. 112:71-74. 
http://dx.doi.org/10.1111/j.1439-0388.1995.tb00543.x

Mu'in, M. A. \& A. Supriyantono. 2012. Identification of $\kappa$-casein polymorphism in bali cattle. J. Agri. Sci. Technol. 397-401.

Nei, M. 1977. F-statistics and analysis of gene diversity in subdivided populations. Ann. Hum. Genet. 41: 225-233. http:// dx.doi.org/10.1111/j.1469-1809.1977.tb01918.x

Nei, M. \& S. Kumar. 2000. Molecular Evolution and Phylogenetics. Oxford University Press, New York.

Noor, R. R. 2008. Genetika Ternak. Penebar Swadaya, Jakarta.

Payne, W. J. A., \& D. H. L. Rollinson. 1973. Bali Cattle. World Anim. Rev. 7:13-21.

Purwantara, B., R. R. Noor, G. Anderson, \& H. Rodriguez-Martinez. 2012. Banteng and Bali cattle in Indonesia: status and forecasts. Reprod. Dom. Anim. 47:2-6. http://dx.doi. org/10.1111/j.1439-0531.2011.01956.x

Rincon J.C., A. Lopez, \& J. Echeverri. 2012. Genetic variability of the bovine prolactin-RsaI loci in Holstein cattle in Antiqouia province (Colombia). Rev. Colomb. Cienc. Pecu. 25:191-201.

Roshanfekr H., S. Sharifi, A. Rastegari, S. R. Khatami, M. Mamouei, \& Kh. Mirzadeh. 2013. Polymorphism of prolactin and growth hormone genes in the Najdi cattle breed using PCR-RFLP. Intl. J. Agri. Corp. Sci. 6:421-423.

Sadeghi, M., M. M. Shahrbabak, G. R. Mianji, \& A. N. Javaremi. 2009. Polymorphism at locus of STAT5A and its association with breeding values of milk production traits in Iranian Holstein bulls. Liv. Sci. 123: 97-100. http://dx.doi. org/10.1016/j.livsci.2008.10.010

Sambrook, J., E. F. Fritsch, \& T. Maniatis. 1989. Molecular Cloning: A Laboratory Manual. $2^{\text {nd }}$ ed. Cold Spring Harbour Laboratory Press, USA.

Selvaggi M., C. Dario, G. Normanno, G. V. Celano, \& M. Dario. 2009. Genetic polymorphism of STAT5A protein: relationship with production traits and milk composition in Italian Brown cattle. J. Dairy Res. 76:441-445. http://dx.doi. org/10.1017/S0022029909990070

Seyfert, H., C. Pitra, L. Meyer, R. M. Brunner, T. T. Wheeler, A. Molenaar, J. Y. McCracken, J. Herrmann, H. Thiesen, \&
M. Schwerin. 2000. Molecular characterization of STAT5Aand STAT5B-encoding genes reveals extended intragenic sequence homogenity in cattle and mouse and different degrees of divergent evolution of various domains. J. Mol. Evol. 50: 550-561.

Siswanto, M., N. W. Patmawati, N. N. Trinayani, I N. Wandia, \& I K. Pudja. 2013. Penampilan reproduksi sapi bali pada peternakan intensif di instalasi pembibitan Pulukan. JIKH. 1: 11-15.

Sodhi, M., M. Mukesh, B. P. Mishra, K. Parvesh, \& B. K. Joshi. 2011. Analysis of genetic variation at the prolactin-RsaI (PRL-RsaI) locus in Indian native cattle breeds (Bos indicus). Biochem. Genet. 49: 39-45. http://dx.doi.org/10.1007/ s10528-010-9383-7

Talib, C. 2002. Sapi bali di daerah sumber bibit dan peluang pengembangannya. WARTAZOA. 12: 100-107.

Tamura, K., D. Peterson, N. Peterson, G. Stecher, M. Nei, \& S. Kumar. 2011. MEGA5: molecular evolutionary genetics analysis using maximum likelihood, evolutionary distance, and maximum parsimony methods. Mol. Biol. Evol. 28: 2731-2739. http://dx.doi.org/10.1093/molbev/msr121

Wakao, H., F. Gouilleux, \& B. Groner. 1994. Mammary gland factor (MGF) is a novel member of the cytokine regulated transcription factor gene family and confers the prolactin response. EMBO J. 13: 2182-2191.

Weir, B. S. 1996. Genetic Data Analysis II: Method for Discrete Population Genetic Data. $2^{\text {nd }}$ ed. Sinauer Associates, Sunderland.

Wojdak-Maksymiec K., M. Kmic, \& J. Strzalaka. 2008. Prolactin gene polymorphism and somatic cell count in dairy cattle. J. Anim. Vet. Adv.7:35-40.

Yeh, F. C., R. C. Yang, \& T. Boyle. 1999. POPGENE version 1.32: Microsoft Window-based Freeware for Population Genetic Analysis. University of Alberta Canada. Edmonton, AB.

Zulkharnaim, Jakaria, \& R. R. Noor. 2010. Identifikasi keragaman genetik gen reseptor hormon pertumbuhan (GHR|AluI) pada sapi bali. Med. Pet. 33: 81-87. http:// dx.doi.org/10.5398/medpet.2010.33.2.81 